\title{
Fertiliser management effects on dissolved inorganic nitrogen in runoff from Australian sugarcane farms
}

\author{
Grant Fraser (D) Ken Rohde • Mark Silburn
}

Received: 14 September 2016 / Accepted: 3 July 2017 / Published online: 21 July 2017

(C) The Author(s) 2017. This article is an open access publication

\begin{abstract}
Dissolved inorganic nitrogen (DIN) movement from Australian sugarcane farms is believed to be a major cause of crown-of-thorns starfish outbreaks which have reduced the Great Barrier Reef coral cover by $21 \%$ (1985-2012). We develop a daily model of DIN concentration in runoff based on $>200$ field monitored runoff events. Runoff DIN concentrations were related to nitrogen fertiliser application rates and decreased after application with time and cumulative rainfall. Runoff after liquid fertiliser applications had higher initial DIN concentrations, though these concentrations diminished more rapidly in comparison to granular fertiliser applications. The model was validated using an independent field dataset and provided reasonable estimates of runoff DIN concentrations based on a number of modelling efficiency score results. The runoff DIN concentration model was combined with a water balance cropping model to investigate temporal aspects of sugarcane fertiliser management. Nitrogen fertiliser application in December (start of
\end{abstract}

G. Fraser $(\bowtie)$

Department of Science, Information Technology and Innovation, Queensland, Australia

e-mail: grant.fraser@qld.gov.au

K. Rohde $\cdot$ M. Silburn

Department of Natural Resources and Mines, Queensland, Australia

M. Silburn

National Centre for Engineering in Agriculture, University of Southern Queensland, Queensland, Australia wet season) had the highest risk of DIN movement, and this was further exacerbated in years with a climate forecast for 'wet' seasonal conditions. The potential utility of a climate forecasting system to predict forthcoming wet months and hence DIN loss risk is demonstrated. Earlier fertiliser application or reducing fertiliser application rates in seasons with a wet climate forecast may markedly reduce runoff DIN loads; however, it is recommended that these findings be tested at a broader scale.

Keywords Nitrogen fertiliser application rates · Climate forecasting · Management - Water quality - Sugarcane . Great Barrier Reef

\section{Introduction}

Dissolved inorganic nitrogen and the Great Barrier Reef

Movement of dissolved inorganic nitrogen (DIN) from fertilised agricultural lands has been identified as a major water quality issue internationally (e.g. Howarth et al. 2002; Schindler et al. 2006; Swaney et al. 2012) and within Australia (e.g. Mitchell et al. 2009; Kroon et al. 2012; Thorburn et al. 2013). Elevated levels of DIN in runoff to the Great Barrier Reef (GBR) are believed to be responsible for large increases $(10 \times)$ in phytoplankton which leads to an increase in larval stage survival of crown-of-thorns starfish (Acanthaster planci) and the potential for crown-of-thorns outbreaks (Brodie et al. 2005). 
Crown-of-thorns is estimated to have caused a $\sim 21 \%$ reduction in GBR coral cover between the years 1985-2012 (De'ath et al. 2012). Sugarcane production occurs in coastal catchments adjoining the GBR (Fig. 1), and it is estimated that runoff DIN loads to the GBR have increased by threefold since preEuropean times (Kroon et al. 2012). Catchments dominated by sugarcane production were found to have the highest median DIN runoff concentrations when compared to a range of other agricultural and non-agricultural land uses (Bartley et al. 2012). Waters et al. (2014) estimated that sugarcane contributes $68 \%$ of the anthropogenic DIN load to the
GBR. To protect the GBR, the Australian government has implemented a Reef Water Quality Protection Plan program which aims to reduce anthropogenic DIN loads to the GBR by 50\% through improving land management practices (Reef Water Quality Protection Plan Secretariat 2013). As sugarcane has the highest concentrations of DIN in runoff and is in close proximity to the GBR, sugarcane farm management of nitrogen fertiliser has been a major focus of the government initiative. To support the program, there have been a number of experiments monitoring DIN runoff loads from sugarcane farms.
Fig. 1 Australian sugarcanegrowing regions that drain into the Great Barrier Reef. Locations of experimental sites are shown

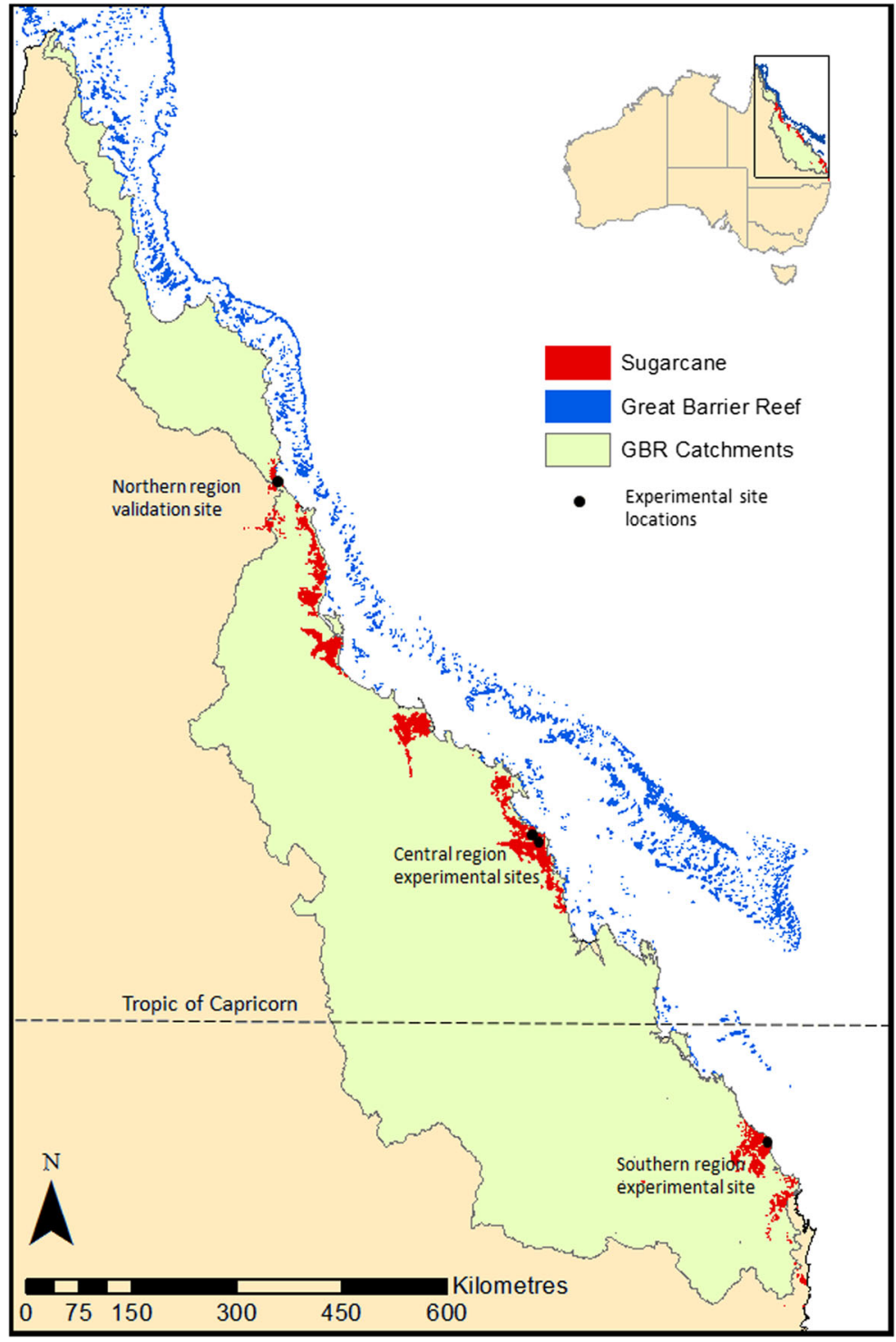


Australian sugarcane farming and fertiliser management practices

In Australia, sugarcane is grown across a range of environments from wet tropics (e.g. northern region, Innisfail-3500 mm), dry tropics (e.g. southern section of northern region, Ayr $1000 \mathrm{~mm}$ ) through to subtropics (e.g. southern region, Childers $880 \mathrm{~mm}$ ). All regions have high inter-annual rainfall variability (average coefficient of variation of 34\%) which is in part, influenced by the El Niño-Southern Oscillation (Allan 1985) and the Pacific Decadal Oscillation (Power et al. 1999). Years with high rainfall can lead to large quantities of runoff and should therefore be the primary focus for management of constituent load generation. Additionally, sugarcane yields can halve under wet conditions (e.g. Schroeder et al. 2010), due to either waterlogging (Rudd and Chardon 1977) or as a result of a reduction in solar radiation (e.g. Inman-Bamber 1995). Hence, sugarcane nitrogen requirements are also potentially reduced in particularly wet years.

Australian sugarcane cropping practices follow a 5to 6-year cycle. The crop is harvested on a $\sim 12$ - to 13month time period. After each harvest, the crop reestablishes from the same rootstock (ratooning) until the third or fourth ratoon whereupon the rootstock is ploughed out. After the final ratoon stage, the land is either left as a bare fallow or a legume such as soybeans or cowpeas is sown. Nitrogen $(\mathrm{N})$ fertiliser is typically applied twice in the plant stage - an initial small amount at planting (e.g. $30 \mathrm{~kg} \mathrm{~N} / \mathrm{ha}$ ) followed by a top-up $\sim 3$ months after planting (e.g. $130 \mathrm{~kg} \mathrm{~N} / \mathrm{ha}$ ). Fertiliser is often applied only once during each ratoon crop with rates being in the range of $130-200 \mathrm{~kg} \mathrm{~N} / \mathrm{ha}$, depending on the productivity of the region. Fertiliser application generally occurs in the 5-month period from late winter (August) through to early summer (December). These time frames are associated with the cane harvesting and planting schedule which occurs during the same time period. There are a number of factors that can affect the timing of fertiliser applications. These include date of harvesting of the previous crop, crop height for machinery access and weather conditions which can affect tractor access.

Australian sugarcane measured runoff DIN loads

Field-measured DIN in runoff provides an opportunity to identify the major impacts of sugarcane farming management practices on DIN loads. Table 1 shows monitored DIN runoff loads on an annual basis and associated experimental details from eight on-farm monitoring experiments. Catchments were in the range of $1500-4300 \mathrm{~m}^{2}$, except for at Ayr where catchments were up to 11.6 ha. DIN loads in runoff vary from being $0.1-11 \%$ of applied nitrogen fertiliser, with a median loss of $1.3 \%$ of applied nitrogen fertiliser (hence having little to no agronomic impact). Understanding the causes of the variability in DIN loads may inform better fertiliser management strategies to minimise DIN losses in runoff. The fate of nitrogen fertiliser in cane farming systems is complex with 11 pathways described by Bristow et al. (1998). However, for most of the sugarcane farm experiments in Table 1 (and for the experiments analysed subsequently), only the runoff DIN pathway has been measured on a daily basis. Processes such as fertiliser transformations, soil $\mathrm{N}$ immobilisation/ mineralisation, $\mathrm{N}$ leaching, denitrification and plant $\mathrm{N}$ uptake have either not been measured or have been measured infrequently. Hence, the development of daily DIN runoff loss model from these datasets cannot aim to represent the variety of soil nitrogen processes known to occur. Nevertheless, these experimental studies do provide information with relation to the range of DIN concentrations in runoff with respect to fertiliser application rates, fertiliser form, timing and rainfall since application. In this study, we develop a daily time-step empirical model of DIN concentrations in runoff that can be easily incorporated into paddock-scale hydrological models and which represent the effects of the main management practices available to sugarcane growers, i.e. $\mathrm{N}$ rate, $\mathrm{N}$ form and timing of application. This runoff DIN concentration model is incorporated into an agricultural water balance and crop growth model to explore the impacts of management using a long-term climate sequence.

\section{Methods}

\section{Experimental site characteristics}

DIN concentrations were measured in surface runoff from three sugarcane experimental trials (Fig. 1) at a paddock scale with catchment areas ranging from 809 to $1569 \mathrm{~m}^{2}$. Two sites (Victoria Plains and Marian) were located in the central sugarcane growing region, and a third site (Wallum Creek) was located in the southern 


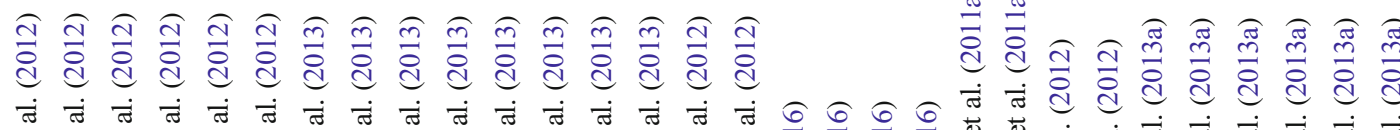

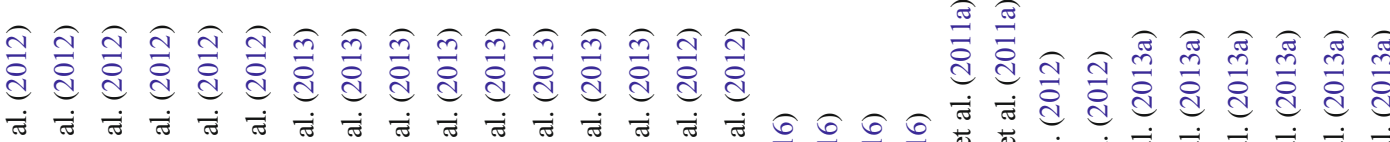

|

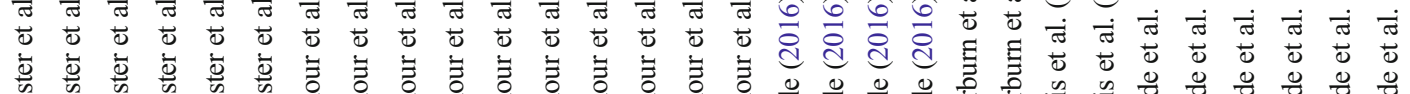

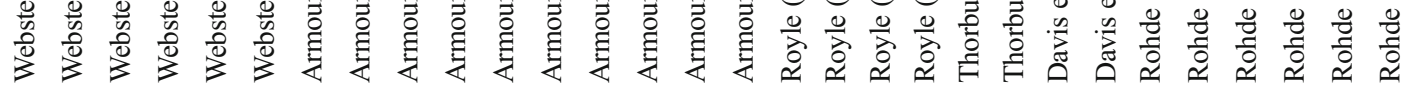

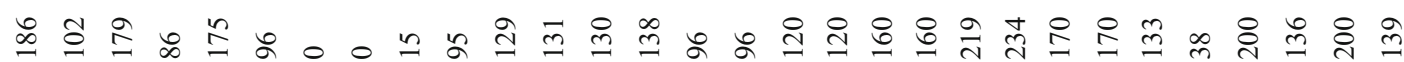

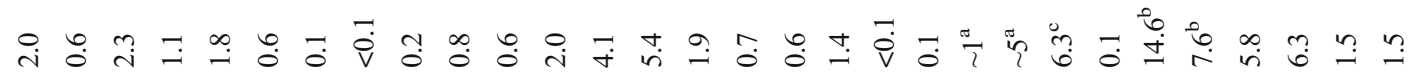
(1) (1)

$\underline{x} \simeq \propto ⿻ 上$

क

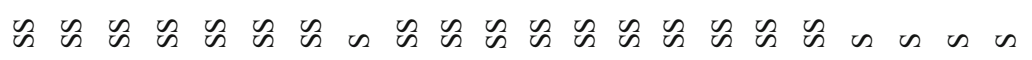

茓茓 究 (1)

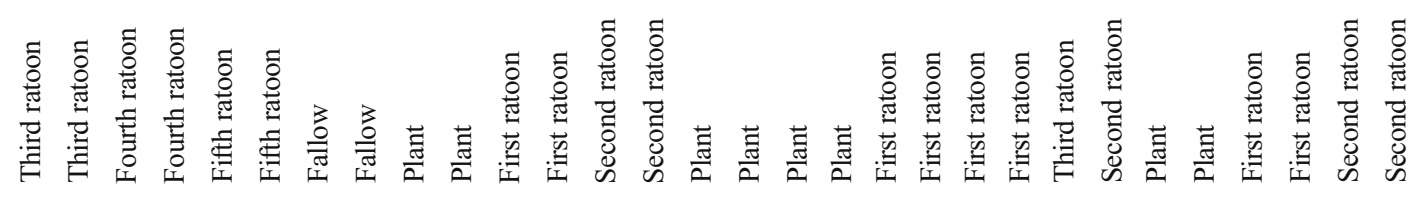

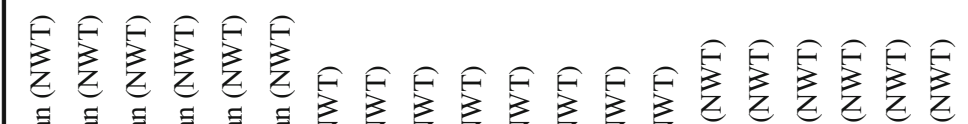

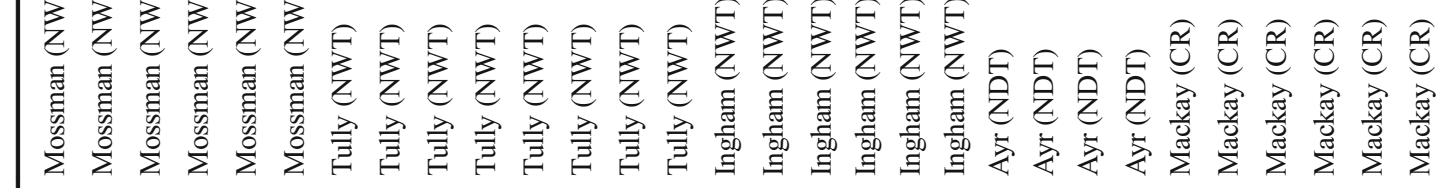




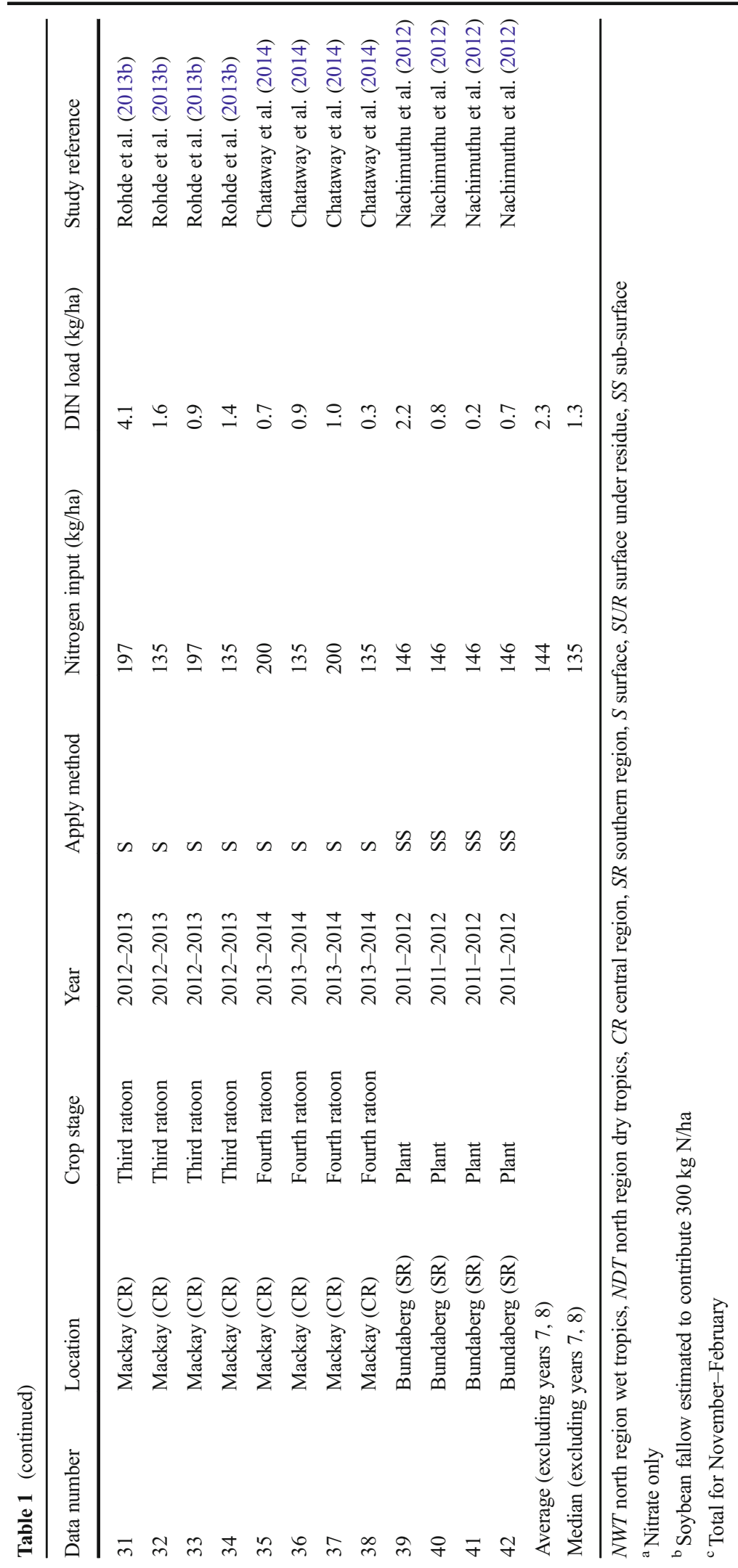




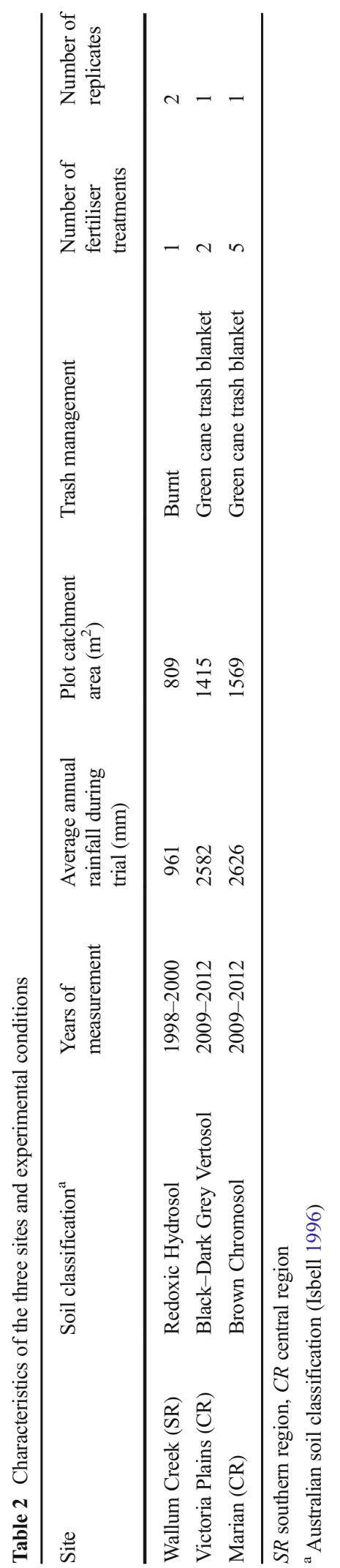

sugarcane growing region. Annual load results for the Victoria Plains site are reported in Table 1, data numbers 25-38. Load measurements were not calculated for the Marian site due to problems with estimating large runoff event volumes. Each site had between two and five runoff plots with flumes and refrigerated pumping samplers. Additionally, each site was located on a different soil type - a sandy-loam soil with a seasonal perched water table (Hydrosol), Brown Chromosol and a selfmulching medium clay (Vertosol) (Table 2). There was a large difference in rainfall measured during the trial period between the two sites in the central region (annual average $\sim 2600 \mathrm{~mm}$ ) and the southern site (annual average $-961 \mathrm{~mm}$ ) (Table 2). The sugarcane harvest residue management also varied, with the cane being burnt at the southern site and retention of green cane residue (locally called green trash blanketing) at the central region sites. Further detailed descriptions of the site characteristics, experimental details, farm management practices and hydrology can be found in (Simpson 2001; Rohde et al. 2013a, b). Fertiliser application dates, fertiliser nitrogen input rates and the form of nitrogen fertiliser were collected for each site (Table 3).

Fertiliser management practices during the experiments

The form of nitrogen fertiliser (granular or liquid) and application rates varied between sites, as well as between years for a given site (Table 3). All fertiliser applications were applied to the surface. There were multiple fertiliser applications per season in some years at the central region farms. In years 16-20, a mix of liquid and granular fertiliser was used; however, the majority of the nitrogen (average $73 \%$ ) was applied in liquid form; for the purposes of categorising each year as being either granular or liquid form, we considered these years to be liquid form. In the first season (20092010) at Victoria Plains, plant cane was established and was preceded by a fallow soybean crop that was incorporated into the soil (to a depth of $10 \mathrm{~cm}$ approximately 6 weeks after being sprayed out with glyphosate herbicide). Although nitrogen content of the soybean crop was not measured at the time of incorporation, the contribution of nitrogen was estimated to be $300 \mathrm{~kg} / \mathrm{ha}$ (Schroeder et al. 2005). This contribution of nitrogen to the system may provide a large proportion of the $\mathrm{N}$ requirements for the forthcoming cane crop (e.g. Park et al. 2010). The nitrogen contribution from the soybean crop will now be considered on the same basis as 


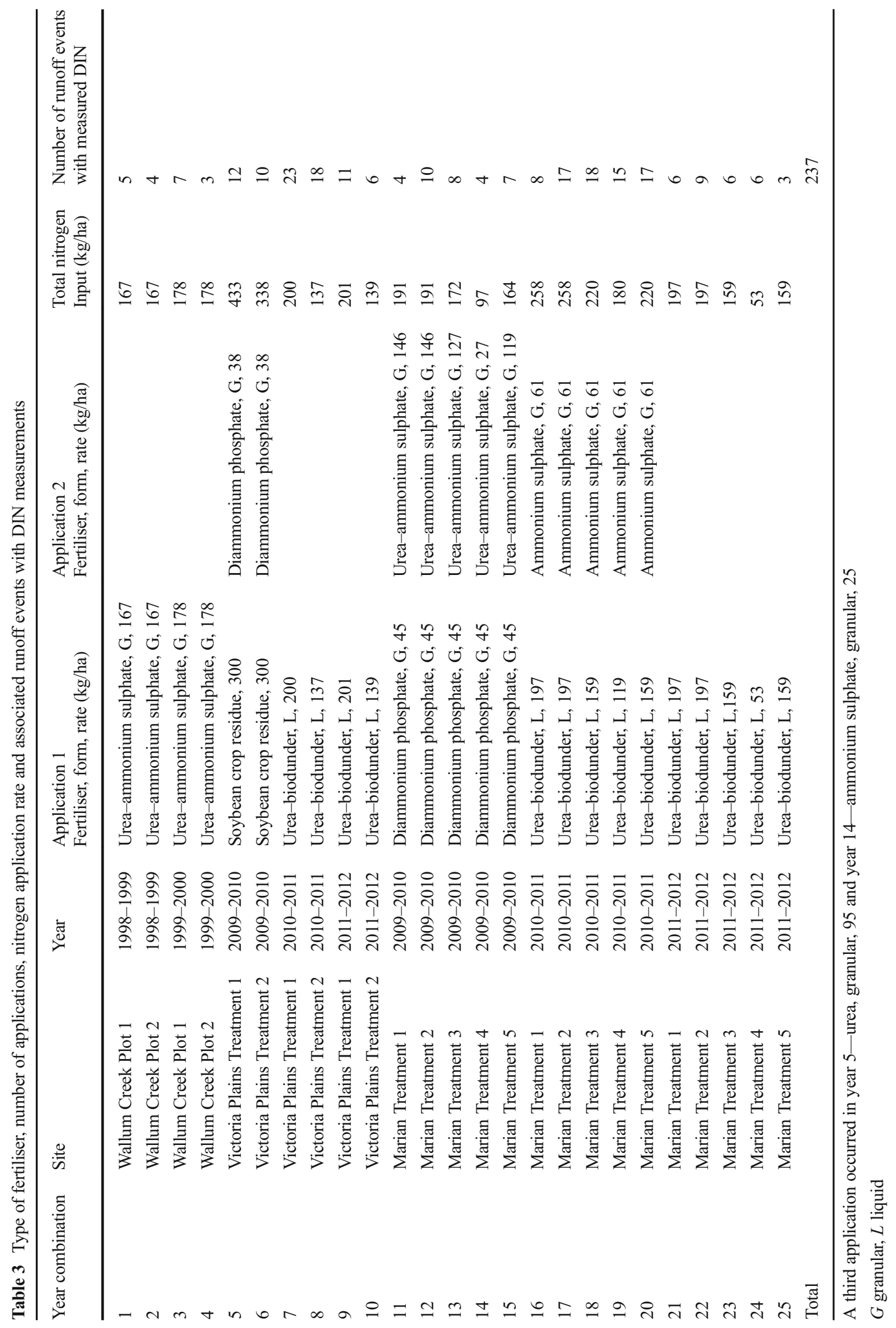


nitrogen contributed from fertiliser applications. One of the commonly applied fertilisers at the central region sites was a surface applied, low concentrate liquid nitrogen and biodunder mix. Biodunder is an organic waste by-product from the cane mill sugar refining process and is usually re-applied to cane fields as a fertiliser. The biodunder component contributed $0.5 \%$ nitrogen to these mixes and the remaining nitrogen came from the addition of liquefied urea.

The number of runoff events with DIN concentration measurements varied greatly across sites and between years, with the 2010-2011 season at the central region sites resulting in the greatest number of runoff events with DIN measurements.

To validate the proposed granular fertiliser model, an independent dataset from a sugarcane site located in the northern cane growing region was used (Webster et al. 2012). At this site, runoff DIN concentrations were measured over three seasons for two nitrogen fertiliser treatments. One fertiliser treatment was based on local standard industry practices $(\mathrm{N}$ farm-Webster et al. 2012), and the nitrogen fertiliser input for the three seasons was 186,179 and $175 \mathrm{~kg} /$ ha each applied as a single surface application of urea prills. The second nitrogen fertiliser treatment was based on 'replacement' of nitrogen ( $\mathrm{N}$ repl-Webster et al. 2012) lost as a result of harvest of the previous year's crop (Thorburn et al. 2011b). In this treatment, nitrogen fertiliser input for the three seasons was 102,86 and $96 \mathrm{~kg} / \mathrm{ha}$ which was applied as a single surface application of urea prills in years 2004, 2006 and sub-surface $(0.1 \mathrm{~m})$ in 2005. The average seasonal rainfall from fertiliser application to early June, the following year was $2393 \mathrm{~mm}$ (similar to two of the calibration sites) and average seasonal runoff was $548 \mathrm{~mm}$. Over the three seasons, 75 runoff events were recorded.

Calibration and application of the HowLeaky model for Victoria Plains

The Victoria Plains sugarcane runoff trial was modelled using the cropping systems model HowLeaky (Freebairn et al. 2003; Thornton et al. 2007; Robinson et al. 2010). HowLeaky simulates the one-dimensional components of the water balance on a daily basis, has a simple crop growth model and was primarily designed to model management impacts on runoff and constituent movement (sediment, pesticides and phosphorus). The objective of the calibration procedure was to attain a representation of daily runoff processes at the site taking into account measured soil characteristics and crop water use. The calibrated model was subsequently used to simulate runoff for the site using a long term climate data sequence.

Field measurements taken during the 3 years of field trial included: daily rainfall; irrigation; soil water content; daily surface runoff; and end of season crop biomass yields. A HowLeaky soil parameter file developed to describe a moderately deep, slowly permeable, Vertosol for the Australian Governments paddock modelling program provided the starting basis for modelling this site (Shaw et al. 2013). The soil water measurements taken during the trial were used to set the upper and lower soil water limits in the model. Additionally, the soil water drainage rate from the bottom soil layer at $2 \mathrm{~m}$ depth was reduced from 5 to $2 \mathrm{~mm} /$ day to represent the presence of a water table which was observed during particularly wet rainfall periods (Table 4). A major factor determining daily runoff rates in HowLeaky is the runoff curve number, which was left at the default setting for this soil type of 78 . This resulted in a coefficient of determination of 0.88 between daily observed runoff and daily modelled runoff (Table 4). The HowLeaky model can be parameterised to represent daily sugarcane crop growth by characterising leaf area development, biomass accumulation and root growth. The key parameter - crop radiation use efficiency — was set to $2.5 \mathrm{~g} / \mathrm{m}^{2} / \mathrm{MJ}$ which was between the $2-3 \mathrm{~g} / \mathrm{m}^{2} / \mathrm{MJ}$ recommended in the HowLeaky. Modelled and observed end of season dry matter yields are shown in Table 4. Planting and harvest dates were set as undertaken in the trial. The only model adjustment made for the subsequent simulation study was to apply $50 \mathrm{~mm}$ of irrigation when the soil water deficit was $>75 \mathrm{~mm}$ with there being at least 15 days between irrigations. This rule was made in the simulation study to represent a farmer irrigating the crop. The simulation study was conducted using the climate record from Pleystowe sugar mill located near the central region sites for the years 1901-2012.

Variability in sugarcane yield and solar radiation

To investigate the effect of solar radiation on cane yields, we accumulated the September-June daily satellite derived solar radiation (Bureau of Meteorology 2009) for the four major cane growing regions in Australia. Daily satellite-derived solar radiation for each 
Table 4 Observed and calibrated HowLeaky model runoff, waterlogging and cane yields on a seasonal basis

\begin{tabular}{llll}
\hline Season & 2009-2010 & 2010-2011 & 2011-2012 \\
\hline Observed runoff (mm) & 815 & 2020 & 950 \\
Predicted runoff (mm) & 978 & 2069 & 1202 \\
Observed days waterlogged & 58 & 177 & 109 \\
Predicted days waterlogged & 78 & 164 & 77 \\
Observed yield (dry matter kg/ha) & 41,824 & 21,265 & 39,882 \\
Predicted yield (dry matter kg/ha) & 40,418 & 23,255 & 38,119 \\
\hline
\end{tabular}

region was based on regionally averaging satellite derived daily solar radiation (Bureau of Meteorology 2009) from $0.05^{\circ}$ grid cells, for cells with greater than $50 \%$ sugarcane land use. Sugarcane mill yield data presented in Schroeder et al. (2010) were aggregated for the four regions.

Application of a climate forecast system to understand DIN runoff risk

The SPOTA-1 (Seasonal Pacific Ocean Temperature Analysis - version 1) climate forecast system Day et al. 2001 was developed based on the relationships between a Queensland Rainfall Index (QRI) and two sea surface temperature indices for the period 19001996. The two sea surface indices are as follows: (1) Norfolk-Hawaii Index (a north-south sea surface temperature anomaly) and (2) South West Pacific Index (a south-west Pacific sea surface temperature anomaly). Independent operational forecasts have been provided online since April 2000 (http://www. longpaddock.qld.gov.au/about-spota1/about.html). SPOTA-1 forecasts are provided on a monthly basis from June through to November each year for the forthcoming seasonal rainfall for December to March. These climate forecasts align to when farmers need to make decisions regarding fertilising their sugarcane crop. Figure 2 shows the relationship between the SPOTA-1 forecast QRI anomaly and the forthcoming seasonal rainfall for the climate station used in the simulation study. While the SPOTA-1 forecast QRI anomaly was not always aligned well with the November-June observed rainfall, there is a relationship between rainfall and the forecast QRI anomaly $\left(r^{2}=0.25, p<0.05\right)$. In the simulation study, the October SPOTA-1 forecast QRI anomaly was classified as being in one of three categories: 'wet', 'average' and 'dry' forecast rainfall conditions. This system of classification was achieved by ranking the forecast QRI anomaly for the years 1900-2013, the top third of the rankings - i.e. those forecasting a wet summer-were assigned to the wet group. Simulated seasonal runoff DIN loads from HowLeaky were also accumulated for the same tercile groups. The simulation study examined the impact of granular and liquid fertiliser applied at close to conventional rates of $170 \mathrm{~kg} \mathrm{~N} / \mathrm{ha}$ and at $85 \mathrm{~kg} \mathrm{~N} /$ ha (i.e. rates similar to the nitrogen replacement system developed by Thorburn et al. 2011b). The date of fertiliser application was the same for both fertiliser application rates.

\section{Results and interpretation}

Development of a model for daily DIN runoff concentration from monitored data

Factors investigated with respect to DIN concentrations in surface runoff were as follows: (a) rainfall since application (including irrigation events); (b) time after application; (c) sediment concentration in runoff; and (d) fertiliser $\mathrm{N}$ application rate (Fig. 3).

Upon visual inspection, three of these factors - time after application, rainfall since application and $\mathrm{N}$ application rate-had an effect on DIN concentrations in runoff, while suspended sediment did not appear to have any consistent effect. The incorporated soybean crop appeared to have a delayed effect on DIN in runoff when compared to fertilisers (Fig. 3a, b). In the case of applied fertilisers, after $\sim 40$ days or $400 \mathrm{~mm}$ of rainfall, there were almost no concentrations above $\sim 1 \mathrm{mg} / \mathrm{l}$ (Fig. 3a, b). However, DIN concentrations did not always decrease sequentially for each subsequent runoff event, with a number of events having runoff DIN concentrations up to 10 times higher than earlier runoff events with low DIN concentrations (e.g. events between 50 and 100 days after application in Fig. 3b). Close 

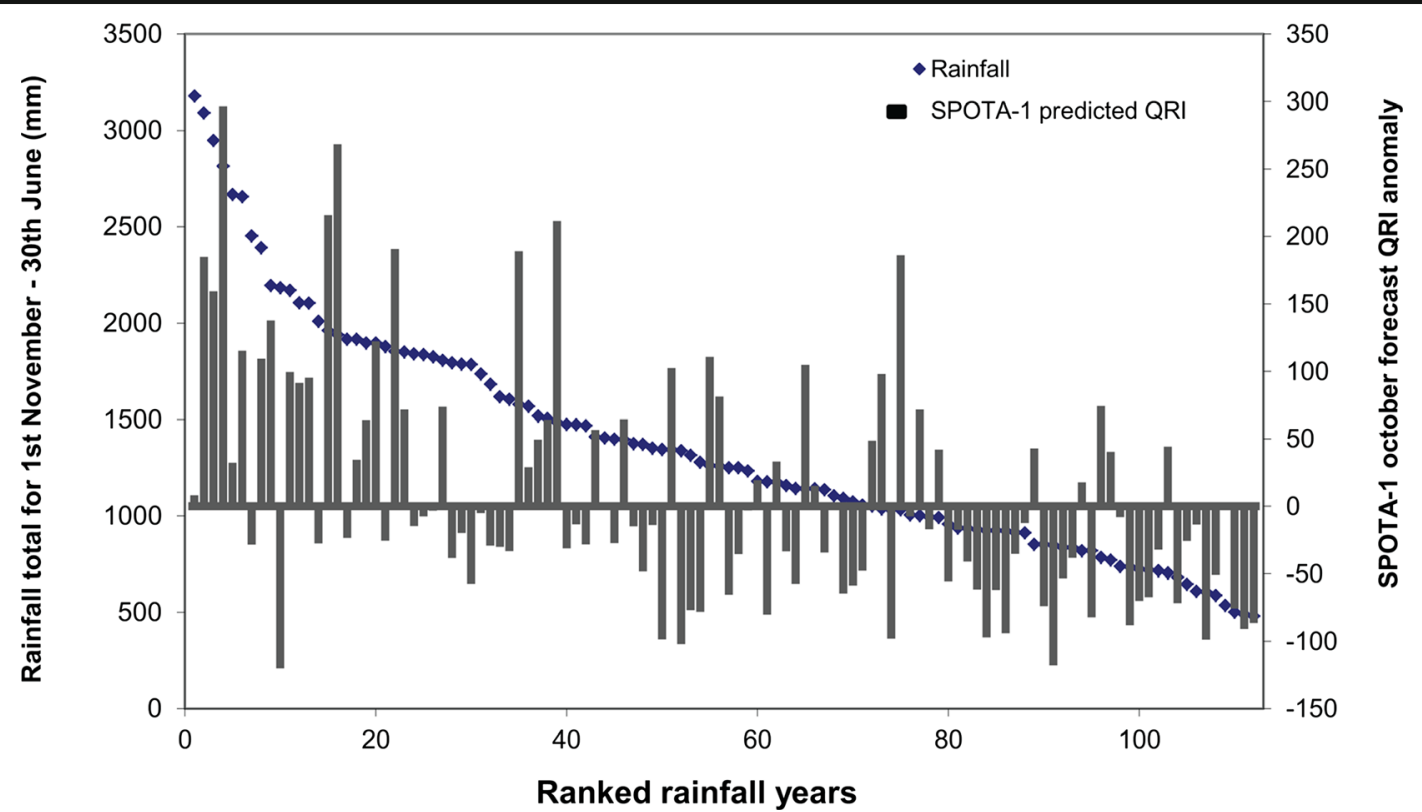

Fig. 2 Accumulated November-June rainfall from Pleystowe station near Victoria Plains and the October SPOTA-1 forecast Queensland Rainfall Index anomaly

inspection of the hydrological conditions for these runoff events revealed that the high DIN concentrations tended to be associated with events that resulted in small runoff quantities of less than $10 \mathrm{~mm}$ (Fig. $4 \mathrm{a}$ ). Another feature of these runoff events was that the time between the events' peak rainfall intensity and the peak runoff was generally greater than $60 \mathrm{~min}$ (Fig. 4b) which suggests an extended residence time for runoff water being in contact with the soil surface. This may allow for more time for surface soil DIN to be assimilated into the runoff water.

As these unusually high DIN concentration events had low runoff volumes, they contributed only a small proportion of the total DIN lost in runoff over a full season. Therefore, these runoff DIN concentration measurements were not included in any further model development ( 7 measurements from the total 237 runoff DIN measurements were excluded).

\section{DIN model development}

Given that there were multiple nitrogen fertiliser applications in 12 of the 25 seasons (Table 3), runoff DIN concentrations could potentially be influenced by one or more fertiliser application depending on when they occurred in the season. In order to develop a DIN model that can be easily implemented in daily water balance models, we aimed to represent the DIN available for runoff as a single pool (i.e. after the first application, subsequent applications can be added to the pool). Given this model form, the performance of the model was assessed on a seasonal basis rather than for each individual DIN concentration. The latter would give an undue weighting to seasons with a large number of runoff events. Hence, model coefficients were optimised based on the model performance over a seasonal basis. Further refinement of the model was done iteratively based on how these model coefficients varied from season to season.

As both time and rainfall since application may be correlated, two independent empirical models of DIN concentrations were developed based on these two components and a third empirical model was developed by combining both these components. Given the occurrence of multiple inputs of nitrogen for a number of seasons at the central region sites, a daily time-step model of DIN concentration in runoff was developed. The three models were-(1) time after application and application rate, (2) rainfall since application and application rate and (3) time after application and rainfall since application and application rate.

Rainfall has been reported to contain low levels of DIN; hence, we set a lower DIN concentration limit for the runoff models. There have been relatively few reported measurements of naturally 

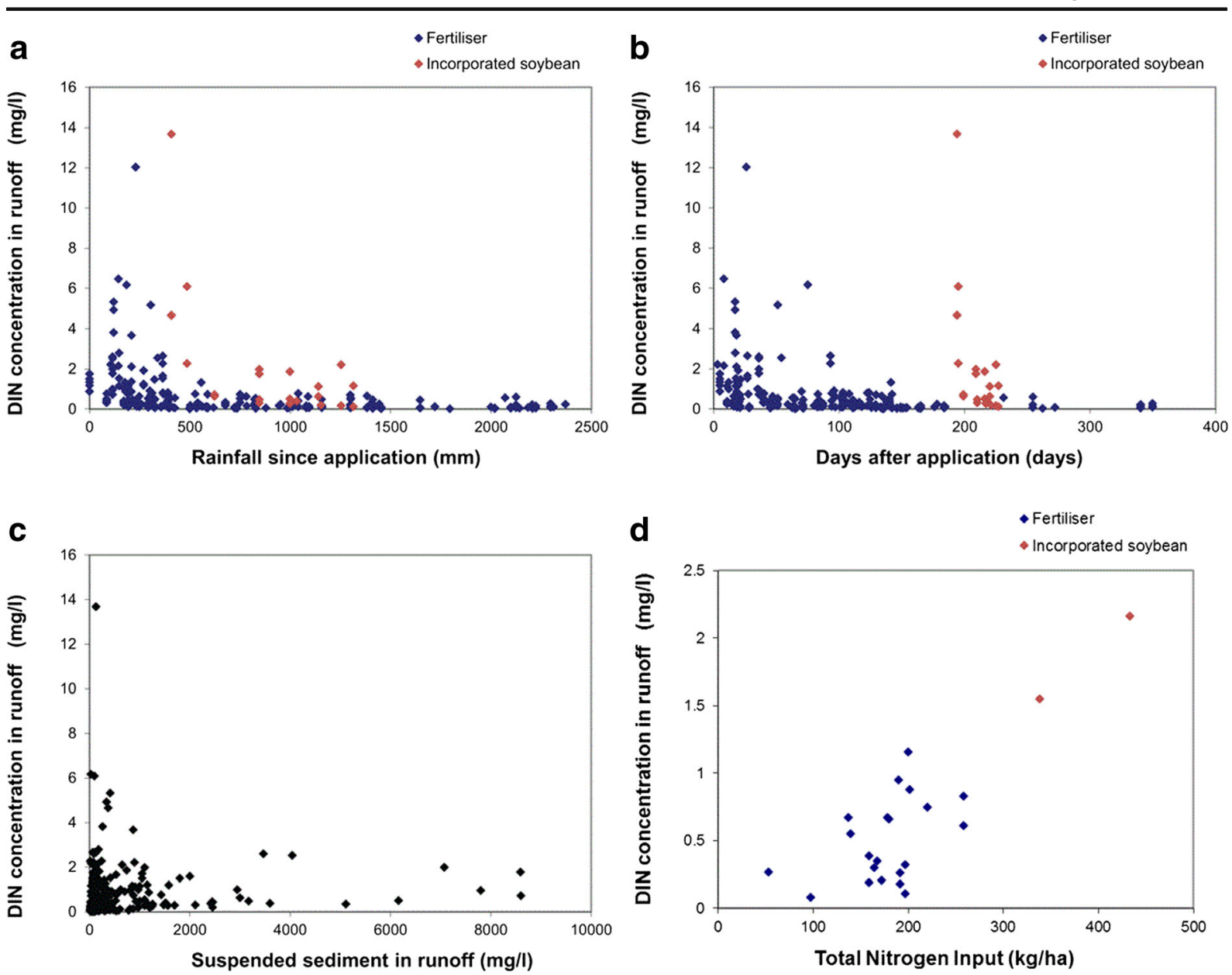

Fig. 3 DIN concentration measured in runoff water relative to a rainfall since application; $\mathbf{b}$ days after application; $\mathbf{c}$ runoff suspended sediment concentrations; and $\mathbf{d}$ total nitrogen input

occurring background levels of DIN in rainfall for coastal areas in Queensland. In the Townsville region, Probert (1976) measured $2.4 \mathrm{~kg}$ DIN/ha/year. Hurditch and Charley (1982) reported a range in measurements from $21 \mathrm{~kg} \mathrm{DIN} / \mathrm{ha} /$ year close to the ocean to $6 \mathrm{~kg} \mathrm{DIN} / \mathrm{ha} /$ year some $2 \mathrm{~km}$ inland in southern Queensland. Taking into account the rainfall quantity at these locations suggests that at the lower end DIN concentrations in rainfall were between 0.02 and $0.045 \mathrm{mg} / \mathrm{l}$. For all recorded runoff at the experimental cane sites, DIN concentration at the fifth percentile was $0.04 \mathrm{mg} / \mathrm{l}$ and was, on average, measured 143 days after the last application of nitrogen fertiliser. Given that this DIN concentration is within the range of the few measured observations for DIN in rainfall, we have set the lower limit in the model so that DIN concentrations in runoff cannot go below $0.04 \mathrm{mg} / \mathrm{l}$.
The form of the three models was as follows:

For each model, runoff concentration on the date of fertiliser application was as follows:

$\mathrm{DIN}_{\mathrm{d} 1}=\mathrm{N}_{\mathrm{i}} \times 1 / k$

1. Time and nitrogen input based model. This will now be referred to as the time based model.

$\mathrm{DIN}_{\mathrm{rt}}=\operatorname{Maximum}\left(0.04, \mathrm{DIN}_{\mathrm{ry}}-\mathrm{DIN}_{\mathrm{ry}} \times \mathrm{DL}\right)$

2. Rainfall and nitrogen input based model. This will now be referred to as the rainfall based model.

$\mathrm{DIN}_{\mathrm{rt}}=$ Maximum $\left(0.04, \mathrm{DIN}_{\mathrm{ry}}-\right.$ Rain $\left.\times \mathrm{RL}\right)$

3. Time, rainfall and nitrogen input based model. This will now be referred to as the time and rainfall based model. 

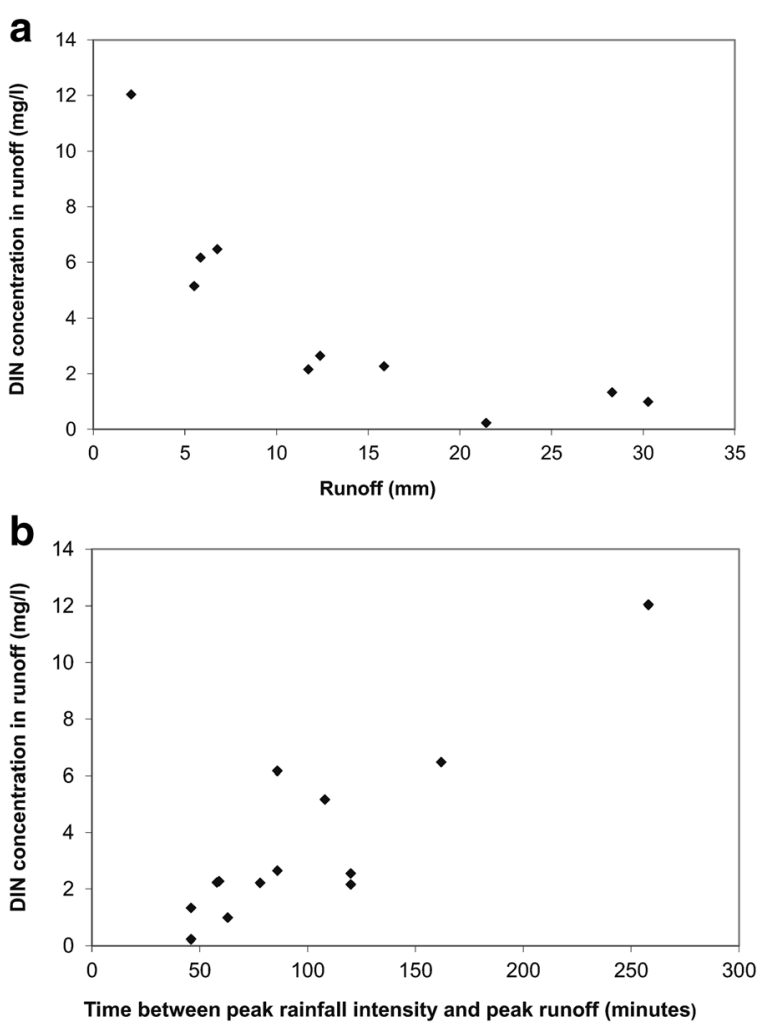

Fig. 4 DIN concentrations for a number of runoff events in the time period between 50 and 100 days after fertiliser application. Intermittent increases in runoff DIN concentrations were associated with small runoff events (a) that also had an extended time between the peak rainfall rate and the peak runoff rate (b)

$\operatorname{DIN}_{\mathrm{rt}}=\operatorname{Maximum}\left(0.04, \mathrm{DIN}_{\mathrm{ry}}-\right.$ Maximum $\left(\right.$ Rain $\left.\left.\times \mathrm{RL}, \mathrm{DIN}_{\mathrm{ry}} \times \mathrm{DL}\right)\right)$

where

$\mathrm{DIN}_{\mathrm{d} 1}$ DIN concentration in runoff water on fertiliser application date $(\mathrm{mg} / \mathrm{l})$

$\mathrm{DIN}_{\mathrm{rt}}$ DIN concentration in runoff water today $(\mathrm{mg} / \mathrm{l})$

DIN $_{\mathrm{ry}}$ DIN concentration in runoff water yesterday $(\mathrm{mg} / \mathrm{l})$

DL Daily loss proportion, fitted model coefficient

$\mathrm{N}_{\mathrm{i}} \quad$ Nitrogen input from fertiliser or plant residue ( $\mathrm{kg} / \mathrm{ha})$

Rain Daily rainfall and irrigation $(\mathrm{mm})$

$1 / k \quad$ Fitted model coefficient to calculate DIN runoff concentration on the day of fertiliser application

RL DIN concentration loss per mm of rainfall / irrigation, fitted model coefficient

When there were multiple fertiliser applications in a season, the new concentration was calculated
as-DIN concentration from the previous day + $\mathrm{Ni} \times 1 / k$.

Each model was optimised for each of the 25 seasons by minimising the mean absolute error between predicted and measured daily DIN concentrations. The parameters that were optimised in each model were as follows: $k$ - divisor of the initial nitrogen fertiliser input; DLthe proportion daily loss of DIN; and RL - the loss of DIN per mm of rainfall. The optimised parameter values and the mean absolute error for each of the models are presented in Table 5.

The rainfall model had a lower mean absolute error than the time model in 19 of the 25 year combinations. Overall the rainfall model had a lower total mean absolute error of $5.9 \mathrm{mg} / \mathrm{l}$ compared to the time model with $7.4 \mathrm{mg} / \mathrm{l}$. The time and rainfall model had the lowest total absolute error of $5.7 \mathrm{mg} / \mathrm{l}$. Although the time and rainfall model did not have a much lower absolute error than the rainfall model, the optimised parameter values for $k$ and RL were less variable than the rainfall model. In the time and rainfall model, the optimised parameter $k$ which determines the initial runoff DIN concentration ranged from 23 to 314 . As the $k$ value and coefficients DL and RL were optimised at the same time, it was possible that a broad range of parameterisations for $k$, DL and RL could result in solutions similar to the optimal solution. In general, the $k$ values for granular fertilisers (years 1-4, 11-15) were larger than for fertilisers applied in a liquid form (years 7-10, 16-25). Therefore, a further optimisation using the time and rainfall model was undertaken based on the form of fertiliser, with three fertiliser forms considered: (a) liquid, (b) granular and (c) incorporated soybean crop.

For this stage of model development, the statistical value 'modelling efficiency', or Nash-Sutcliffe model efficiency coefficient (Mayer and Butler 1993) was used to evaluate model performance. Modelling efficiency is considered a better indication of the 'effectiveness' of model predictions, with values ranging from negative infinity to positive one. A value of positive one indicates that the model is perfect at predicting the unknown value, a value of zero indicates that the mean of the observations is as good as using the model and negative values indicate that the model was worse than using the mean of the observed values. Model efficiency values greater than 0 indicate that the model provides a better estimate than using a site measured event mean DIN concentration. The parameters $k, \mathrm{RL}$ and $\mathrm{DL}$ were optimised using Microsoft Excel Solver to achieve the 
Table 5 Parameter values for the three DIN models optimised for each year of measurement and the associated mean absolute error (MAE)

\begin{tabular}{|c|c|c|c|c|c|c|c|c|c|c|}
\hline \multirow[t]{2}{*}{ Year } & \multicolumn{3}{|c|}{ Time } & \multicolumn{3}{|c|}{ Rainfall } & \multicolumn{4}{|c|}{ Time and rainfall } \\
\hline & $k$ & $\mathrm{DL}$ & MAE & $k$ & $\mathrm{RL}$ & MAE & $k$ & DL & RL & MAE \\
\hline 1 & 300 & 0.0052 & 0.04 & 340 & 0.0004 & 0.04 & 314 & 0.0032 & 0.0002 & 0.04 \\
\hline 2 & 91 & 0.0349 & 0.08 & 240 & 0.0021 & 0.07 & 188 & 0.0099 & 0.0019 & 0.07 \\
\hline 3 & 51 & 0.0266 & 0.14 & 183 & 0.0019 & 0.26 & 53 & 0.0257 & 0.0003 & 0.14 \\
\hline 4 & 39 & 0.0213 & 0.06 & 65 & 0.0057 & 0.28 & 37 & 0.0221 & 0.0049 & 0.16 \\
\hline 5 & 59 & 0.0142 & 1.92 & 31 & 0.0161 & 1.19 & 23 & 0.0036 & 0.0112 & 1.24 \\
\hline 6 & 43 & 0.0062 & 0.95 & 116 & 0.0014 & 0.87 & 86 & 0.0019 & 0.0013 & 0.87 \\
\hline 7 & 80 & 0.0399 & 0.28 & 90 & 0.0051 & 0.25 & 89 & 0.0030 & 0.0049 & 0.25 \\
\hline 8 & 56 & 0.0340 & 0.13 & 62 & 0.0044 & 0.11 & 58 & 0.0199 & 0.0044 & 0.12 \\
\hline 9 & 10 & 0.0400 & 0.30 & 32 & 0.0107 & 0.09 & 29 & 0.0026 & 0.0103 & 0.10 \\
\hline 10 & 10 & 0.0315 & 0.49 & 26 & 0.0074 & 0.19 & 24 & 0.0020 & 0.0073 & 0.19 \\
\hline 11 & 10 & 0.0367 & 0.04 & 133 & 0.0016 & 0.01 & 54 & 0.0011 & 0.0043 & 0.01 \\
\hline 12 & 169 & 0.0123 & 0.07 & 265 & 0.0004 & 0.03 & 219 & 0.0024 & 0.0004 & 0.03 \\
\hline 13 & 10 & 0.0338 & 0.12 & 187 & 0.0005 & 0.06 & 52 & 0.0020 & 0.0041 & 0.11 \\
\hline 14 & 139 & 0.0129 & 0.04 & 100 & 0.0007 & 0.07 & 118 & 0.0020 & 0.0004 & 0.02 \\
\hline 15 & 10 & 0.0312 & 0.19 & 266 & 0.0003 & 0.17 & 160 & 0.0020 & 0.0005 & 0.14 \\
\hline 16 & 62 & 0.0459 & 0.21 & 90 & 0.0039 & 0.20 & 89 & 0.0010 & 0.0039 & 0.20 \\
\hline 17 & 59 & 0.0518 & 0.51 & 74 & 0.0026 & 0.43 & 68 & 0.0098 & 0.0023 & 0.43 \\
\hline 18 & 32 & 0.0670 & 0.35 & 71 & 0.0025 & 0.30 & 73 & 0.0013 & 0.0024 & 0.30 \\
\hline 19 & 104 & 0.0212 & 0.38 & 51 & 0.0024 & 0.33 & 50 & 0.0103 & 0.0022 & 0.33 \\
\hline 20 & 21 & 0.0576 & 0.52 & 50 & 0.0035 & 0.47 & 53 & 0.0021 & 0.0032 & 0.47 \\
\hline 21 & 63 & 0.0211 & 0.27 & 55 & 0.0048 & 0.24 & 46 & 0.0010 & 0.0053 & 0.24 \\
\hline 22 & 21 & 0.0304 & 0.03 & 91 & 0.0093 & 0.04 & 93 & 0.0020 & 0.0080 & 0.04 \\
\hline 23 & 10 & 0.0355 & 0.02 & 94 & 0.0069 & 0.04 & 50 & 0.0197 & 0.0012 & 0.02 \\
\hline 24 & 165 & 0.1000 & 0.18 & 69 & 0.0049 & 0.07 & 66 & 0.0010 & 0.0045 & 0.09 \\
\hline 25 & 10 & 0.0225 & 0.14 & 60 & 0.0032 & 0.07 & 51 & 0.0041 & 0.0023 & 0.03 \\
\hline Median & 51 & 0.0315 & - & 90 & 0.0032 & - & 58 & 0.0024 & 0.0032 & - \\
\hline SD & 60 & 0.0302 & & 19 & 0.0023 & & 18 & 0.0073 & 0.0024 & \\
\hline Total & - & - & 7.4 & - & - & 5.9 & - & - & & 5.7 \\
\hline
\end{tabular}

$k$ divisor for $\mathrm{N}$ input, $D L$ daily loss proportion, $R L$ loss of DIN per mm rainfall (mg/l/mm), MAE mean absolute error between predicted and modelled DIN concentrations (mg/l), SD standard deviation

maximum Nash-Sutcliffe efficiency for the granular and liquid nitrogen fertiliser applications (Table 6). There were 2 years when soybean crop residue was incorporated into the surface soil as a source of nitrogen for the plant sugarcane crop. Twenty-two runoff events occurred in these 2 years. In one of these years, an additional $95 \mathrm{~kg} / \mathrm{ha}$ of nitrogen was added as urea fertiliser 84 days after the soybean crop was incorporated. As runoff events in this year began 195 days after application, using either of the liquid or granular fertiliser parameterisations would result in minimal contribution from the urea application to surface runoff DIN concentrations. Therefore, these 2 years have been parameterised solely based on the addition of nitrogen to the soil from the soybean crops. The soybean parameters (Table 6) result in five to 10 times lower daily loss rate when compared to the fertiliser applications.

The granular fertiliser model had a $k$ value of almost twice the liquid fertiliser model indicating the initial availability of DIN from liquid fertilisers is almost twice that of the fertilisers applied in a granular form. The granular based fertilisers had about twice the daily loss rate compared to the liquid fertilisers, but runoff DIN concentrations did not decrease as a result of rainfall. 
Table 6 The optimised parameter values for different nitrogen fertiliser forms — granular based, liquid based and soybean using the time and rainfall model

\begin{tabular}{llllllll}
\hline Nitrogen input & $\begin{array}{l}\text { Number of years } \\
\text { model was based on }\end{array}$ & $\begin{array}{l}\text { Minimum DIN } \\
\text { concentration } \\
(\mathrm{mg} / \mathrm{l})\end{array}$ & $k$ & DL & RL & $\begin{array}{c}\text { MAE } \\
\text { Modelling } \\
\text { efficiency }\end{array}$ \\
\hline Granular fertiliser & 9 & 0.11 & 111 & 0.014 & 0.0001 & 0.24 & 0.38 \\
Liquid fertiliser & 14 & 0.04 & 54 & 0.0075 & 0.0053 & 0.37 & 0.50 \\
Incorporated soybean & 2 & 0.04 & 50 & 0.0015 & 0.0045 & 0.17 & 0.51 \\
\hline
\end{tabular}

$k$ divisor for $\mathrm{N}$ input, $D L$ daily loss proportion, $R L$ loss of DIN per $\mathrm{mm}$ rainfall $(\mathrm{mg} / \mathrm{l} / \mathrm{mm})$

This was also seen in the measurements of DIN at the end of season with granular fertilisers having a higher base level of runoff DIN concentration of $0.11 \mathrm{mg} / \mathrm{l}$ compared to $0.04 \mathrm{mg} / \mathrm{l}$ for the liquid fertilisers.

Validation of the 'granular fertiliser' parameterised DIN model

The granular fertiliser model was tested by using an independent field site with runoff DIN measurements, which is briefly described in the methods section. In addition to the granular fertiliser DIN model, a parameterisation based on the median parameter result in Table 5 was tested. The 'granular' fertiliser model performed the best out of the two models tested based on both the mean absolute error and the modelling efficiency score (Table 7). Optimising the model parameters for the validation data resulted in slightly different parameterisation, with a small improvement in both the mean absolute error and modelling efficiency.

The total DIN load for the treatment with the lower nitrogen fertiliser rate ( $\mathrm{N}$ replacement) was predicted (granular parameters) accurately; however, the load for the treatment with the higher fertiliser application rate ( $\mathrm{N}$ farm) (Fig. 5) was under predicted. Importantly, the model represented the disproportionate contribution of DIN load from early season rainfall events (i.e. $\sim 50 \%$ of the total DIN load has occurred from $\sim 25 \%$ of the seasonal rainfall). This is an important finding from analysing the monitored DIN data and will be important for understanding the interactive effects of fertiliser application timing and seasonal rainfall conditions.

Effect of fertiliser management practices on runoff DIN loads

The DIN model developed in this study was combined with the calibrated HowLeaky model for Victoria Plains to investigate the interaction between long-term climate conditions and DIN runoff losses. The fertiliser management practices investigated were as follows: (a) application timing (i.e. September-December), (b) nitrogen fertiliser application rate and (c) fertiliser form (granular/liquid), with results shown in Fig. 6a, b.

Application timing had only a minor effect on the rate of DIN lost in runoff for the low rate of fertiliser application of $85 \mathrm{~kg} / \mathrm{ha}$, especially for the liquid fertiliser form. For application rates close to industry standard recommended rates (i.e. $170 \mathrm{~kg} / \mathrm{ha}$ ), application timing did have a significant effect on DIN loads with the December applications having $>3$ times the runoff DIN loads compared to September applications. For the December application, the granular fertiliser (applied at $170 \mathrm{~kg} / \mathrm{ha}$ ) was nearly

Table 7 Performance of two empirical DIN models on the validation data and a parameter set optimised for the validation data is presented

\begin{tabular}{llrlllr}
\hline Model & $\begin{array}{l}\text { Minimum DIN } \\
\text { concentration (mg/l) }\end{array}$ & $k$ & DL & RL & Meanabsolute error & Modelling efficiency \\
\hline Median & 0.04 & 58 & 0.002 & 0.0032 & 0.33 & -0.29 \\
Granular & 0.11 & 111 & 0.014 & 0.0001 & 0.24 & 0.24 \\
Optimised & 0.11 & 102 & 0.011 & 0.0001 & 0.24 & 0.29 \\
\hline
\end{tabular}

$k$ divisor for $\mathrm{N}$ input, $D L$ daily loss proportion, $R L$ loss of DIN per mm rainfall (mg/l/mm) 


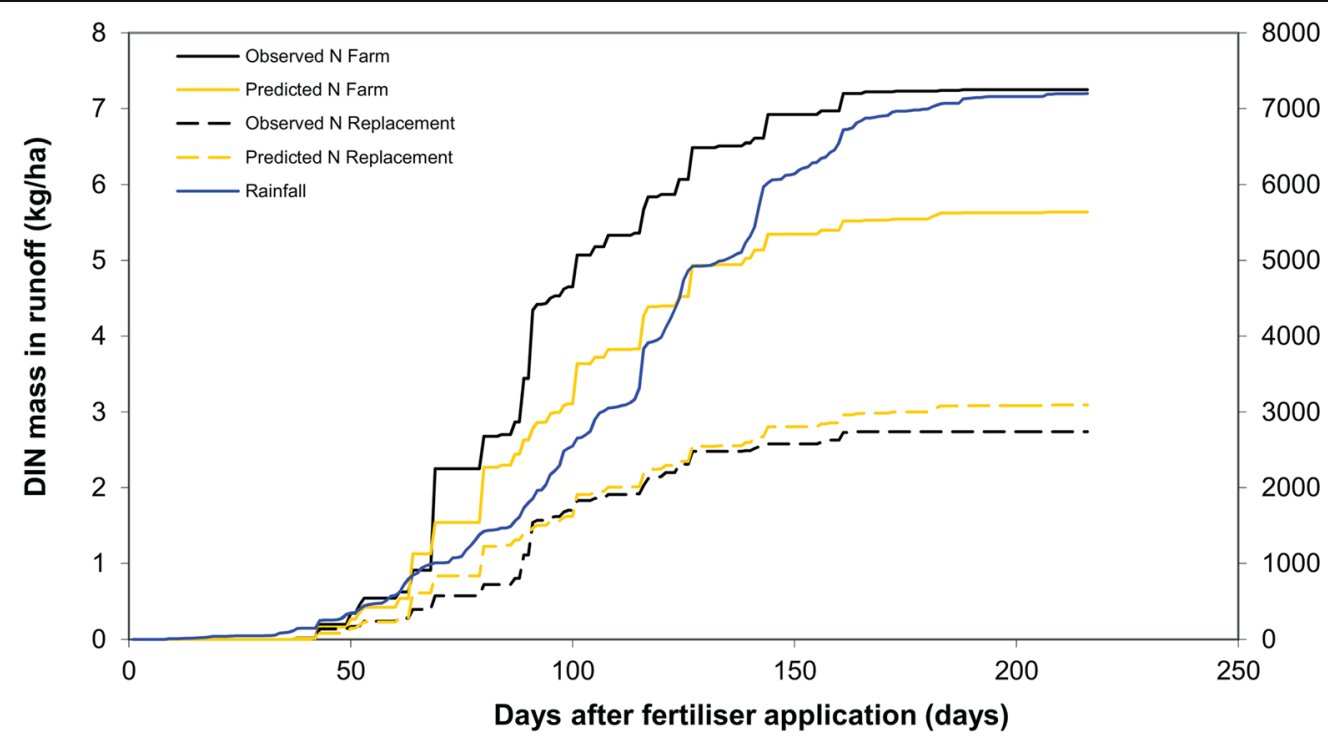

Fig. 5 Cumulative measured and predicted (using the granular parameterisation) runoff DIN loads $(\mathrm{kg} \mathrm{N} / \mathrm{ha}$ ) for the validation site $\mathrm{N}$ farm and $\mathrm{N}$ replacement treatments. Rainfall, measured and

twice the rate of DIN loss when compared to the liquid fertiliser.

Relationship between solar radiation and cane yields

When the accumulated solar radiation is compared to the average mill yields, the derived relationship has a coefficient of determination of $0.45, p<0.05$ (Fig. 7). Inman-Bamber (1995) found that relatively small reductions in incident solar radiation can lead to large decreases in cane sucrose yield. The impacts of reduced solar radiation are explained as being due to two interrelationships: firstly, a reduction in solar radiation reduces temperature that in turn slows down canopy development and its ability to intercept solar radiation, and secondly, from the direct impact of a reduction in incident solar radiation. Hence, in years that are forecast to be particularly wet with associated lower solar radiation and cane yields, reduced rates of nitrogen fertiliser application may be a management option.

Using a seasonal climate forecast to estimate runoff DIN load risk

The median runoff DIN load in years that were forecast to be wet were $4.1 \mathrm{~kg} /$ ha for granular and $2.1 \mathrm{~kg} / \mathrm{ha}$ for liquid fertiliser applications when applied at the $170 \mathrm{~kg} \mathrm{~N} /$ ha rate (Fig. 8). In contrast, the median runoff observed DIN load data have been accumulated concurrently from the date of fertiliser application which was set as day 0 for each of the three seasons

DIN loads in the combined grouping for forecast dry + average years were $1.5 \mathrm{~kg} / \mathrm{ha}$ for granular and $0.8 \mathrm{~kg} / \mathrm{ha}$ for liquid fertiliser applications when applied at the $170 \mathrm{~kg} / \mathrm{ha}$ rate. This indicates that the median runoff DIN loads in wet years are on average $170 \%$ greater than in forecast dry + average climate years. By applying the lower rate of nitrogen fertiliser $(85 \mathrm{~kg} \mathrm{~N} / \mathrm{ha})$ in this December period for wet forecast years, the median DIN loads were $2.1 \mathrm{~kg} / \mathrm{ha}$ for the granular fertiliser, and $0.45 \mathrm{~kg} / \mathrm{ha}$ for the liquid fertiliser. These median DIN loads were similar to those for forecast average climate years for the granular fertiliser and forecast dry climate conditions for the liquid fertiliser when applying $170 \mathrm{~kg} \mathrm{~N} / \mathrm{ha}$.

\section{Discussion}

The daily runoff DIN concentration model developed in this study can easily be implemented in daily water balance models such as HowLeaky without the requirement to develop and parameterise a nitrogen balance model. The model has been developed from field measurements covering a diverse range of climates, soil types, nitrogen fertiliser input rates and fertiliser types. In particular, it represents the decline in runoff DIN concentrations after granular or liquid nitrogen fertiliser application, which was a key feature of the 

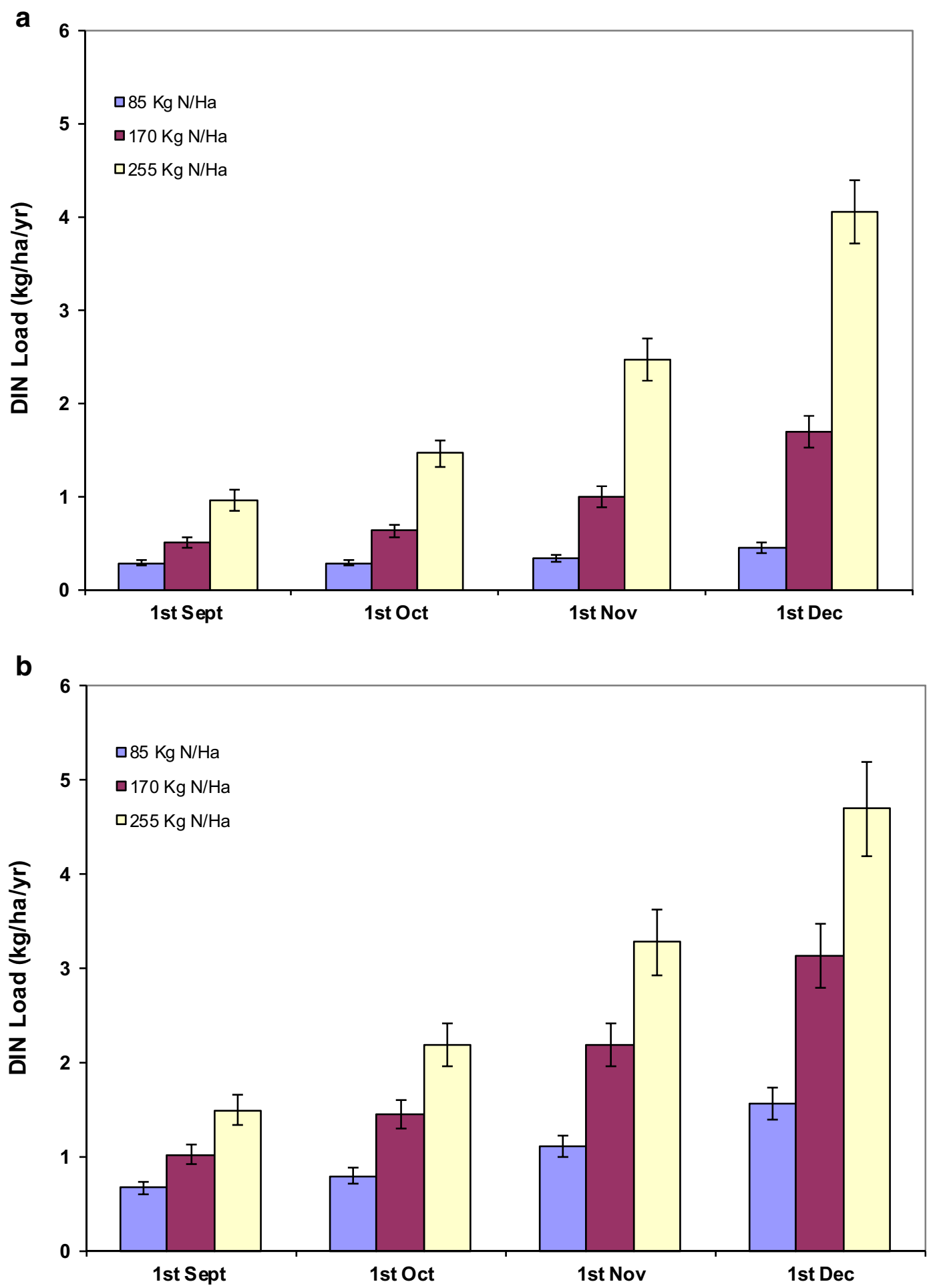

Fig. 6 Predicted average annual DIN load and standard errors for a liquid and $\mathbf{b}$ granular nitrogen fertilisers applied at three rates- 85,170 and $255 \mathrm{~kg} \mathrm{~N} / \mathrm{ha}$ at four different application times. Standard error bars are shown 


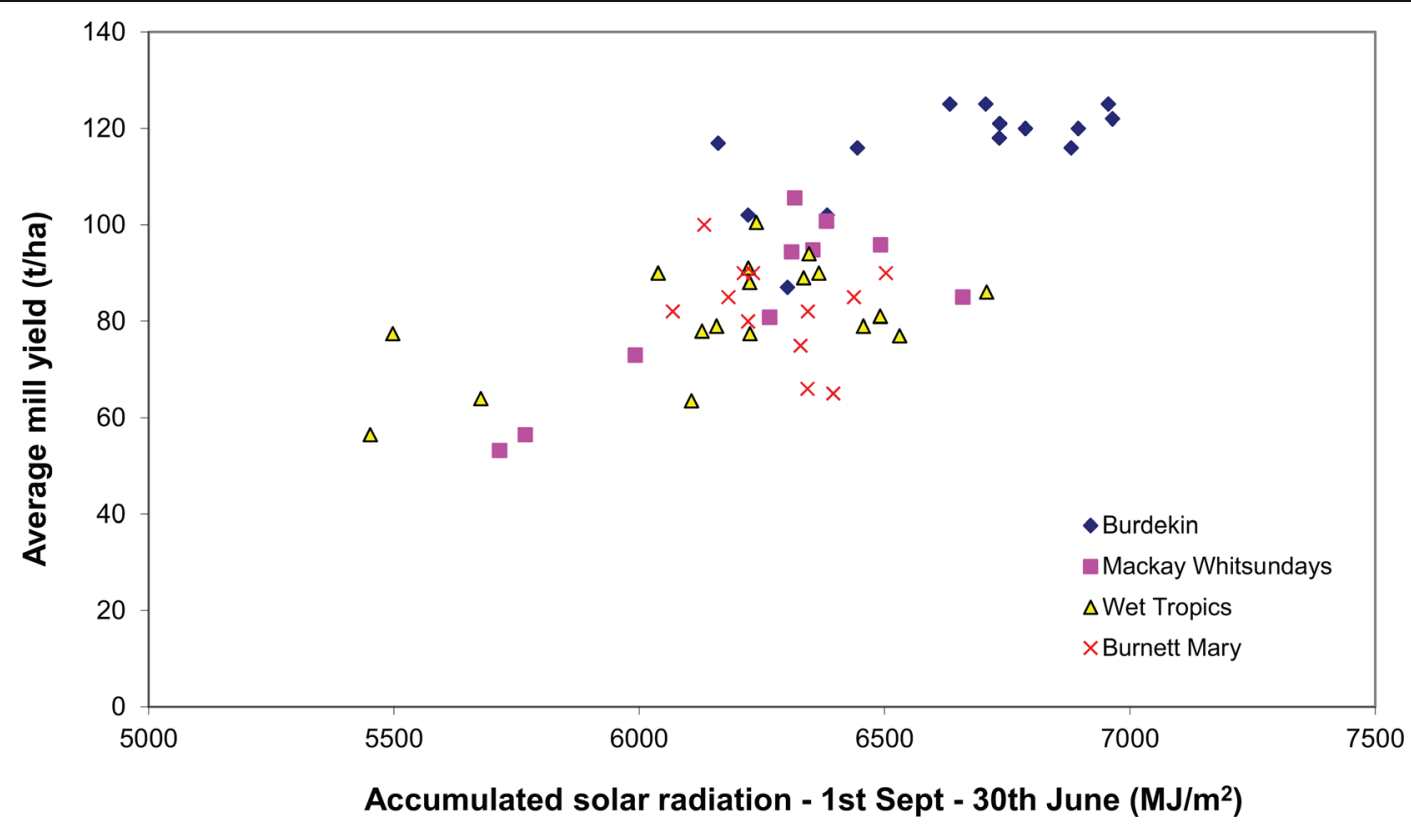

Fig. 7 Accumulated solar radiation and average mill yield for the four major cane growing regions of Queensland

field measured dataset. This decline in runoff DIN concentrations after fertiliser application has also been observed in other field runoff studies. For example, Sharpley et al. (1982) and Barlow et al. (2007) found runoff DIN concentrations from fertilised pastures decreased greatly 1 month after fertiliser applications of 60 and $\sim 358 \mathrm{~kg} \mathrm{~N} / \mathrm{ha}$, respectively. In contrast, the incorporated soybean crop parameterisation (Table 6) had
Fig. 8 Runoff DIN load in the SPOTA-1 forecast 'wet', 'average' and 'dry' years when the nitrogen application rate was 170 or $85 \mathrm{~kg} /$ ha for a liquid fertiliser and $\mathbf{b}$ granular fertiliser
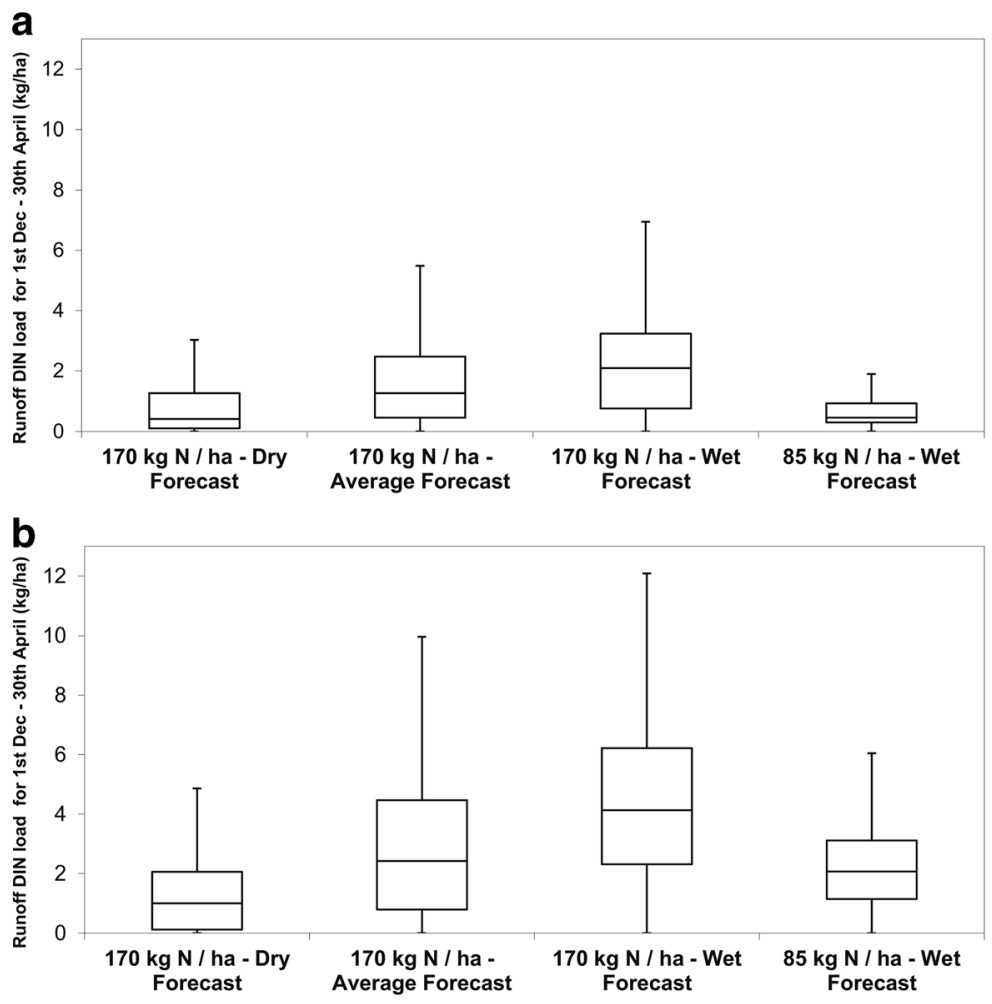
much slower rates of decline in potential runoff DIN concentrations when compared to granular and liquid fertiliser applications. Thus, for a large soybean crop, there is a higher risk of generating high runoff DIN loads for up to 6 months after incorporation.

For the DIN model developed in this study, the rate of urea hydrolysis is thought to be an important aspect affecting the DIN model coefficient values and is believed to be the reason for the higher runoff DIN risk associated with using surface applied granular fertilisers compared to surface applied liquid fertilisers. The slower rate of hydrolysis of surface applied granular fertiliser may be due to fertiliser getting caught up in the large amounts of surface residue (e.g. 10-20 t dry matter/ha; Thorburn et al. 2001), which may limit both dissolution and metabolisation by soil bacteria. An interesting study by Prasertsak et al. (2002) found that by burying urea fertiliser in soil with sufficient moisture, hydrolysis commenced immediately and was complete after 2 days, compared to only $68 \%$ of urea being hydrolysed for surface applications. Improvements in the DIN model that explicitly represent these initial transformation processes will allow for better representation of fertiliser timing on runoff DIN and also dissolved organic nitrogen (e.g. Davis et al. 2016).

\section{Management options to reduce sugarcane DIN runoff} loads

The simulation study results indicate the importance of fertiliser timing and seasonal rainfall conditions have on DIN runoff loads. Obviously, earlier application before the onset of the wet season reduces DIN losses; however, there are practical limits to how much the timing of fertiliser application can be altered due to the cane harvesting schedule. Sugarcane fertiliser application amounts are generally a set amount year-in and yearout with the aim of matching fertiliser $\mathrm{N}$ rates to crop requirements. The relationship between yield and solar radiation (Fig. 7) results presented here indicate that crop nitrogen requirements will likely vary year-to-year. Additionally, studies of isotopically labelled Nitrogen fertiliser show that of the nitrogen fertiliser applied only $1-49 \%$ is taken up by the crop (Bell 2015). These results suggest that fertiliser application rates could be reduced in high runoff risk years. Those being-when fertiliser is being applied close to the onset of the wet season and for when there is a forecast for particularly wet summer season. For the single location used in the simulation study provided here, we estimate that by reducing late season nitrogen fertiliser rates in these high risk years DIN losses from granular fertiliser were reduced by $49 \%$ and from liquid fertiliser by $78 \%$. However, broader application and testing is recommended.

The study results suggest that the following strategies may be useful to reduce the risk of runoff DIN loads:

- Use liquid fertilisers instead of granular fertilisers

- Avoid late application of fertiliser leading into the wet season

- Irrigate (overhead) after liquid fertiliser application

- Reduce $\mathrm{N}$ fertiliser rates in forecast wet years

The model does not include the effects of below ground fertiliser placement compared to surface application or the impacts of banding of fertilisers on the crop row. Both of these are relatively common practices and indicate the potential for further model development. Additionally the model was developed from cane grown in predominantly rainfall fed conditions and may not be applicable for cane regions which have quite different furrow irrigation practices such as in the north Queensland dry tropics region.

\section{Conclusion}

The daily empirical runoff DIN concentration model developed in this study can be easily incorporated into basic cropping systems models. The model allows for the effects of several key management practices (rate, time and form of fertiliser application) to be modelled. The simulation study results highlight the risk of late season fertiliser application and suggest that further investigation regarding the utility of a climate forecast to inform fertiliser management decisions be undertaken.

Acknowledgements The authors are grateful to Mr. Tony Webster (CSIRO) who generously provided the validation data used in this study. We also thank Queensland Government colleagues Melanie Shaw, John Armour and Phil Moody for valuable feedback on early versions of the manuscript.

Open Access This article is distributed under the terms of the Creative Commons Attribution 4.0 International License (http:// creativecommons.org/licenses/by/4.0/), which permits unrestricted use, distribution, and reproduction in any medium, provided you give appropriate credit to the original author(s) and the source, provide a link to the Creative Commons license, and indicate if changes were made. 


\section{References}

Allan, R. J. (1985). The Australasian summer monsoon, teleconnections, and flooding in the Lake Eyre Basin. Adelaide: Royal Geographical Society of Australasia, S. A. Branch.

Armour, J., Davis, D., Masters, B., Whitten, M., Mortimore, C., \& Bainbridge, Z. (2012). Paddock scale water quality monitoring of sugarcane and banana management practices: interim technical report 2010/2011 wet season, wet tropics region. Australia: Queensland Department of Natural Resources and Mines, Centre for Tropical Water \& Aquatic Ecosystem Research and Queensland Department of Agriculture, Fisheries and Forestry for Terrain Natural Resource Management.

Armour, J., Davis, A., Masters, B., Mortimore, C., \& Whitten, M. (2013). Paddock Scale water quality monitoring of sugarcane and banana management practices: interim technical report 2011/2012 wet season, wet tropics region. Australia: Queensland Department of Natural Resources and Mines, Centre for Tropical Water \& Aquatic Ecosystem Research and Queensland Department of Agriculture, Fisheries and Forestry for Terrain Natural Resource Management.

Barlow, K., Nash, D., Hannah, M., \& Robertson, F. (2007). The effect of fertiliser and grazing on nitrogen export in surface runoff from rain-fed and irrigated pastures in south-eastern Australia. Nutrient Cycling in Agroecosystems, 77, 69-82.

Bartley, R., Speirs, W. J., Ellis, T. W., \& Waters, D. K. (2012). A review of sediment and nutrient concentration data from Australia for use in catchment water quality models. Marine Pollution Bulletin, 65, 101-116.

Bell, M. J. (Ed.) (2015). A review of nitrogen use efficiency in sugarcane. Australia: Sugar Research Australia.

Bristow, K. L., Thorburn, P. J., Sweeney, C. A. and Bohl, H. P. (1998). Water and nitrogen balance in natural and agricultural systems in the wet tropics of north Queensland: a review. Australia: Land and Water Resources Research and Development Corporation.

Brodie, J., Fabricus, K., De'ath, G., \& Okaji, K. (2005). Are increased nutrient inputs responsible for more outbreaks of the crown-of-thorns starfish? An appraisal of the evidence. Marine Pollution Bulletin, 51, 266-278.

Bureau of Meteorology (2009). Solar exposure data derived from satellite imagery processed by the Bureau of Meteorology from the Geostationary Meteorological Satellite series operated by Japan Meteorological Agency and from GOES-9 operated by the National Oceanographic \& Atmospheric Administration (NOAA) for the Japan Meteorological Agency.

Chataway, R., Donaldson, S., Robins, S., Rohde, K. and Agnew, J. (2014). Paddock to sub-catchment water quality monitoring of sugarcane management practices. Technical Report 2013/ 14 Wet Season, Mackay Whitsunday Region. Australia: Queensland Department of Natural Resources and Mines, Queensland Government.

Davis, A., Milla, R., Bainbridge, Z., \& Ginders, M. (2012). Paddock scale water quality monitoring interim technical report for 2010-2011, lower Burdekin sugarcane region. Australia: Australian Centre for Tropical Freshwater
Research and Queensland Department of Employment, Economic Development \& Innovation for NQ Dry Tropics * note this is draft report prepared as part of the Australian governments 'Paddock to Reef' program.

Davis, A. M., Tink, M., Rohde, K., \& Brodie, J. E. (2016). Urea contributions to dissolved 'organic' nitrogen losses from intensive, fertilised agriculture. Agriculture, Ecosystems \& Environment, 223, 190-196.

Day, K. A., Ahrens, D. G. \& McKeon, G. M. (2001). Queensland Summer Rainfall in Relation to Sea-Surface Temperature in the Previous March. Seasonal Pacific Ocean Temperature Analysis - 1, Report 1, 2001/2. Queensland Department of Environment and Resource Management, Brisbane.

De'ath, G., Fabricus, K. E., Sweatman, H., Puotinen, M. (2012). The 27-year decline of coral cover on the Great Barrier Reef and its causes. Proceedings of the National Academy of Sciences of the United States of America, 109(44), 1799517999.

Freebairn, D. M., McClymont, D., Rattray, D., Owens, J., Robinson, J. B., \& Silburn, D. M. (2003). Howleaky? An instructive model for exploring the impact of different land uses on water balance and water quality. Proceedings of the 9th PUR\$L National Conference, Yeppoon (Vol. 29).

Howarth, R. W., Sharpley, A., \& Walker, D. (2002). Sources of nutrient pollution to coastal waters in the United States: implications for achieving coastal water quality goals. Estuaries, 25(4), 656-676.

Hurditch, W. J. \& Charley, J. L. (1982). Sulfur and nitrogen relationships in coastal forests. Cycling of carbon, nitrogen, sulfur and phosphorus in terrestrial and aquatic ecosystems. New York: Springer-Verlag, 25-33.

Inman-Bamber, N. G. (1995). Climate and water as constraints to production in the South African Sugar Industry. Proceedings of The South African Sugar Technologists' Association, 69, 55-59.

Isbell, R. F. (1996). The Australian soil classification. Melbourne: CSIRO.

Kroon, F. J., Kuhnert, P. M., Henderson, B. L., Wilkinson, S. N., Kinsey-Henderson, A., Abbott, B., Brodie, J. E., \& Turner, R. D. R. (2012). River loads of suspended solids, nitrogen, phosphorus and herbicides delivered to the Great Barrier Reef lagoon. Marine Pollution Bulletin, 65, 167-181.

Mayer, D. G., \& Butler, D. G. (1993). Statistical validation. Ecological Modelling, 68, 21-32.

Mitchell, A., Reghenzani, J., Faithful, J., Furnas, M., \& Brodie, J. (2009). Relationships between land use and nutrient concentrations in streams draining a 'wet-tropics' catchment in northern Australia. Marine and Freshwater Research, 60(11), 1097-1108.

Nachimuthu, G., Halpin, N., \& Bell, M. (2012). Paddock to subcatchment scale water quality monitoring of vegetablesugarcane farming systems. Technical report 2011-2012, Burnett Mary Region. Australia: Queensland Department of Agriculture, Fisheries and Forestry, Queensland (DAFFQ) and The University of Queensland (QAAFI).

Park, S. E., Webster, T. J., Horan, H. L., James, A. T., \& Thorburn, P. J. (2010). A legume rotation crop lessens the need for nitrogen fertiliser throughout the sugarcane cropping cycle. Field Crops Research, 119(2), 331-341.

Power, S., Casey, T., Folland, C., Colman, A., \& Mehta, V. (1999). Interdecadal modulation of the impact of ENSO on Australia. 
Climate Dynamics, 15, 319-324. doi:10.1007 /s003820050284.

Prasertsak, P., Freney, J. R., Denmead, O. T., Saffigna, P. G., Prove, B. G., \& Reghenzani, J. R. (2002). Effect of fertilizer placement on nitrogen loss from sugarcane in tropical Queensland. Nutrient Cycling in Agroecosystems, 62(3), 229-239.

Probert, M. E. (1976). The composition of rainwater at two sites near Townsville, Queensland. Australian Journal of Soil Research, 14, 397-402.

Reef Water Quality Protection Plan Secretariat (2013). Securing the health and resilience of the Great Barrier Reef World Heritage Area and adjacent catchments. The State of Queensland: Australian Government, Queensland Government.

Robinson, J. B., Silburn, D. M., Rattray, D., Freebairn, D. M., Biggs, A. J. W., McClymont, D., \& Christodoulou, N. (2010). Modelling shows that the high rates of deep drainage in parts of the Goondoola Basin in semi-arid Queensland can be reduced with changes to the farming systems. Australian Journal of Soil Research, 48, 58-68.

Rohde, K., McDuffie, K., Agnew, J. (2013a). Paddock to subcatchment scale water quality monitoring of sugarcane management practices. Final report 2009/10-2011/12 wet seasons, Mackay Whitsunday region. Australia: Queensland Department of Natural Resources and Mines, 80p.

Rohde, K., McDuffie, K., \& Agnew, J. (2013b). Paddock to subcatchment scale water quality monitoring of sugarcane management practices. Interim report 2012/13 wet season, Mackay Whitsunday Region. Australia: Department of Natural Resources and Mines, Queensland Government for Reef Catchments (Mackay Whitsunday Isaac) Limited.

Royle, A. (2016). Nutrient loss in runoff from sugarcane in the Herbert catchment. Wet tropics region "P2R2-Herbert Demo Farm \#2" Final Report 2013-2015. Australia: Herbert Cane Productivity Services Limited.

Rudd, A. V. \& Chardon C. W (1977). The effects of drainage on cane yields as measured by water table height in the Macknade Mill area. Australia: 44th Conference of the Queensland Society of Sugar Cane Technology.

Schindler, D. W., Dillon, P. J., \& Schreier, H. (2006). A review of anthropogenic sources of nitrogen and their effects on Canadian aquatic ecosystems. Biogeochemistry, 79(1-2), $25-44$.

Schroeder, B. L., Wood, A. W., Moody, P. W., Bell, M. J., \& Garside, A. L. (2005). Nitrogen fertiliser guidelines in perspective. Proceedings of the Australian Society of Sugarcane Technologists, 27, 291-304.

Schroeder, B. L., Hurney, A. P., Wood, A. W., \& Moody, P. W. (2010). Concepts and value of the nitrogen guidelines contained in the Australian sugar industry's 'six easy steps' nutrient management program. Proceedings of the International Society of Sugar Cane Technologists, 27, 11.

Sharpley, A. N., Syers, J. K., \& Tillman, R. W. (1982). Transport of ammonium- and nitrate-nitrogen in surface runoff from pasture as influenced by urea application. Water, Air, and Soil Pollution, 20, 425-430.

Shaw, M., Silburn, D. M., Ellis, R., Searle, R., Biggs, J., Thorburn, P., \& Whish, G. (2013). Paddock scale modelling to assess effectiveness of agricultural management practice in improving water quality in the Great Barrier Reef Catchments. Perth: 20th International Congress on Modelling and Simulation.

Simpson, B. W. (2001). Offsite movement of agrochemicals in tropical sugarcane production: Extension workshop (p. 113). Bundaberg: Queensland Department of Natural Resources and Mines.

Swaney, D. P., Hong, B., Ti, C., Howarth, R. W., \& Humborg, C. (2012). Net anthropogenic nitrogen inputs to watersheds and riverine $\mathrm{N}$ export to coastal waters: a brief overview. Current Opinion in Environmental Sustainability, 4(2), 203-211.

Thorburn, P. J., Probert, M. E., \& Robertson, F. A. (2001). Modelling decomposition of sugar cane surface residues with APSIM-residue. Field Crops Research, 70, 223-232.

Thorburn, P. J., Biggs, J. S., Attard, S. J., \& Kemei, J. (2011a). Environmental impacts of irrigated sugarcane production: nitrogen lost through runoff and leaching. Agriculture, Ecosystems and Environment, 144, 1-12.

Thorburn, P. J., Biggs, J. S., Webster, A. J., \& Biggs, I. M. (2011b). An improved way to determine nitrogen fertiliser requirements of sugarcane crops to meet global environmental challenges. Plant and Soil, 339, 51-67.

Thorburn, P. J., Wilkinson, S. N., \& Silburn, D. M. (2013). Water quality in agricultural lands draining to the Great Barrier Reef: a review of causes, management and priorities. Agriculture, Ecosystems and Environment, 180, 4-20.

Thornton, C. M., Cowie, B. A., Freebairn, D. M., \& Playford, C. L. (2007). The Brigalow catchment study: II. Clearing brigalow (Acacia harpophylla) for cropping or pasture increases runoff. Australian Journal of Soil Research, 45, 496511.

Waters, D. K., Carroll, C., Ellis, R., Hateley, L., McCloskey, G. L., Packett, R., Dougall, C., \& Fentie, B. (2014). Modelling reductions of pollutant loads due to improved management practices in the Great Barrier Reef catchments-whole of $G B R$, technical report (Vol. Vol 1). Toowoomba: Queensland Department of Natural Resources and Mines.

Webster, A. J., Bartley, R., Armour, J. D., Brodie, J. E., \& Thorburn, P. J. (2012). Reducing dissolved inorganic nitrogen in surface runoff water from sugarcane production systems. Marine Pollution Bulletin, 65, 128-135. 